\title{
Effect of carbohydrate source on productive performance, ruminal and systemic health of grazing cows
}

\author{
Efecto de la fuente de carbohidratos sobre el desempeño productivo, la salud ruminal y sistémica de \\ vacas en pastoreo
}

Efeito da fonte de carboidratos sobre o desempenho produtivo, saúde ruminal e sistêmica de vacas em pastejo

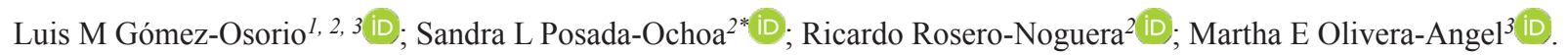

\begin{abstract}
${ }^{1}$ Grupo de Investigación y Desarrollo Nutri-Solla, SOLLA S.A., P.O . Box 1252, Medellín, Colombia.
${ }^{2}$ Grupo de Investigación en Ciencias Agrarias GRICA, Facultad de Ciencias Agrarias, Universidad de Antioquia, P.O. Box 1226, Medellin, Colombia.

${ }^{3}$ Grupo de Investigación Biogenesis, Facultad de Ciencias Agrarias, Universidad de Antioquia, P.O. Box 1226, Medellín, Colombia.
\end{abstract}

To cite this article:

Gómez-Osorio LM, Posada-Ochoa SL, Rosero-Noguera R, Olivera-Angel ME. Effect of carbohydrate source on productive performance, ruminal and systemic health of grazing cows. Rev Colomb Cienc Pecu 2020; 33(4): 204-216. DOI: https://doi.org/10.17533/udea.rccp.v33n4a01

\begin{abstract}
Background: The nutritional limitations of Cenchrus clandestinus -i.e., high protein and low energy concentrationsmake it necessary to supplement cows with non-fibrous carbohydrate (NFC) sources to improve productive performance. Nevertheless, such supplementation can lead to ruminal acidosis. Objective: To evaluate partial replacement of corn grain (Zea mays, ZM) with sorghum grain (Sorghum vulgare, SV), cassava root (Manihot esculenta, MES) or citrus pulp (Citrus sp., C) on milk yield and quality, ruminal $\mathrm{pH}$ and health of grazing cows. Methods: Eight Holstein cows were evaluated in a $4 \mathrm{x} 4$ Latin square design during the first 60 days of lactation. Treatments (isoenergetic rations, $1.45 \pm 0.003 \mathrm{Mcal} \mathrm{NE} / \mathrm{kg} \mathrm{DM}$ ) consisted of a mixture of grass and four concentrates with different NFC sources. Results: No differences in dry matter intake, feed efficiency, ruminal $\mathrm{pH}$, hematological and metabolic profile were observed between treatments. Rumen $\mathrm{pH}$ was higher than 6.0, confirming the absence of ruminal acidosis. Milk yield (energy-corrected), protein, and total solids were higher for MES vs. C. Conclusions: None of the NFC sources tested compromised the ruminal or systemic health of the cows, while MES improved milk yield and quality.
\end{abstract}

Keywords: cassava; cereal grains; citrus pulp; dairy cattle; energy source; feed efficiency; lameness; non-fibrous carbohydrates; ruminal acidosis; starch.

Received: May 15, 2019; accepted: April 16, 2020

*Corresponding author. Carrera 75 \#65-87, Medellín (Antioquia, Colombia). Tel.: +5742196524. E-mail: sandra.posada@udea.edu.co 


\section{Resumen}

Antecedentes: las limitaciones nutricionales del Cenchrus clandestinus (alta concentración de proteína y baja densidad energética) hacen necesario suplementar las vacas con fuentes de carbohidratos no fibrosos (NFC) para mejorar su desempeño productivo. Sin embargo, esta suplementación puede generar acidosis ruminal. Objetivo: evaluar el reemplazo parcial de maíz (Zea mays, ZM) por sorgo (Sorghum vulgare, SV), yuca (Manihot esculenta, MES) o pulpa cítrica (Citrus sp., C) sobre la producción de leche y su calidad, el pH ruminal y la salud de vacas en pastoreo. Métodos: ocho vacas Holstein fueron evaluadas empleando un diseño en cuadrado latino de 4 x 4 durante los primeros 60 días de lactancia. Los tratamientos (raciones isoenergéticas, 1,45 $\pm 0,003 \mathrm{Mcal} \mathrm{NE}_{\mathrm{L}} / \mathrm{kg} \mathrm{MS}$ ) consistieron de una mezcla de forraje y cuatro concentrados con diferentes fuentes de NFC. Resultados: no se observaron diferencias entre tratamientos en cuanto a consumo de materia seca, eficiencia alimenticia, pH ruminal, ni perfiles hematológico y metabólico. El pH ruminal fue mayor a 6,0; confirmando la ausencia de acidosis. La producción de leche (corregida por energía), proteína, y sólidos totales fue mayor para MES vs. C. Conclusiones: ninguna de las fuentes de NFC evaluadas comprometieron la salud ruminal o sistémica de las vacas, y MES mejoró la producción de leche y su calidad.

Palabras clave: acidosis ruminal; almidón; carbohidratos no fibrosos; eficiencia alimenticia; fuente de energia; ganado lechero; granos de cereales; laminitis; pulpa citrica; yuca.

\section{Resumo}

Antecedentes: as limitações nutricionais do Cenchrus clandestinus-alta concentração de proteína e baixa densidade de energia- faz necessário suplementar às vacas com fontes de carboidratos não-fibrosos (NFC) para melhorar o desempenho produtivo. No entanto, essa suplementação pode gerar acidose ruminal. Objetivo: avaliar a substituição parcial do milho (Zea mays, ZM) por sorgo (Sorghum vulgare, SV), mandioca (Manihot esculenta, MES) ou polpa cítrica (Citrus sp., C) na produção e qualidade do leite, $\mathrm{pH}$ ruminal e a saúde de vacas em pastejo. Métodos: oito vacas Holandesas foram avaliadas empregando um delineamento em quadrado latino 4 × 4 durante os primeiros 60 dias de lactação. Os tratamentos (rações isoenergéticas, $1,45 \pm 0,003$ Mcal $\mathrm{NE}_{\mathrm{L}} / \mathrm{kg} \mathrm{DM}$ ) consistiram de uma mistura de forragem e quatro concentrados com diferentes fontes de NFC. Resultados: não foram observadas diferenças entre os tratamentos no consumo de matéria seca, eficiência alimentar, pH ruminal, perfil hematológico e metabólico. O pH ruminal foi superior a 6,0; confirmando a ausência de acidose ruminal. A produção do leite (corrigida para energia), proteína e sólidos totais foi maior para MES vs. C. Conclusões: nenhuma das fontes de NFC avaliadas comprometeu a saúde ruminal e sistêmica das vacas, embora o MES melhorou a produção e qualidade do leite.

Palavras-chave: acidose ruminal; amido; carboidratos não fibrosos; eficiência alimentar; fonte de energia; gado leiteiro; grãos de cereais; laminite; mandioca; polpa citrica. 


\section{Introduction}

Kikuyu grass (Cenchrus clandestinus) is widely used in Colombia as grazing forage for dairy cattle. As a forage base, kikuyu has nutritional limitations, such as excessive protein and low energy contents, which commonly result in milk yields lower than $11 \mathrm{~kg} / \mathrm{cow} / \mathrm{d}$ (Marais, 2001). Accordingly, non-fibrous carbohydrates (NFC) content should be increased in the diet of lactating cows in order to improve energy availability in the rumen.

Corn (Zea mays) is the most widely used energy source in dairy feeds because it is rich in starch, representing $72 \%$ of the grain (Tabasum et al., 2018). Other NFC sources, such as sorghum (Sorghum vulgare), cassava (Manihot esculenta) and citrus pulp (derived from Citrus genus) are of interest because they do not compete with human food sources. In comparison to corn, starch content is similar in sorghum (Huntington et al., 2006), higher in cassava (84\%; Santana and Meireles, 2014), and lower in citrus pulp (2.3\%); although the latter has higher sugar $(24.1 \%)$ and pectin $(22.3 \%)$ concentration (Bampidis and Robinson, 2006).

Rapidly-fermenting carbohydrate sources improve MY and quality, but it can compromise animal health by increasing the risk of subacute ruminal acidosis (SARA). In pasture-based production systems typical of the Colombian high tropics forage is offered ad libitum and cows are fed a concentrate supplement twice-aday during milking, which increases SARA risk.

Researchers have studied this disorder by inducing sudden changes in the diet of nonlactating animals (Li et al., 2012; Gao and Oba, 2016; Jing et al., 2018), but the effects on yield and milk composition remain unclear. Therefore, it is important to evaluate the effect of NFC-rich ingredients on SARA incidence and performance of lactating cows. Therefore, the objective of this study was to evaluate a partial replacement of corn grain in the ration with sorghum grain, cassava root, or citrus pulp on MY and quality, ruminal $\mathrm{pH}$, and animal health of grazing Holstein cows.

\section{Materials and Methods}

\section{Ethical Considerations}

This study was approved by the Ethics Committee for Animal Experimentation at Universidad de Antioquia (act 76, May 2012, Medellin-Colombia).

\section{Location, animals and experimental design}

The experiment was conducted in Santa Rosa de Osos municipality (Antioquia, Colombia). Eight Holstein-Friesian cows averaging $534 \pm$ $34 \mathrm{~kg}$ body weight (BW) were used in a $4 \times 4$ replicated Latin square design, resulting in 32 experimental observations. The calving number effect was considered in the experimental design, with third-calving cows assigned to the first square and those with fourth and fifth calvings to the second square. The study was conducted during the first 60 days (d) postpartum. The duration of each period was $15 \mathrm{~d}$, with $10 \mathrm{~d}$ for adaptation and $5 \mathrm{~d}$ for the experimental period.

\section{Experimental diets and feeding}

Animals were managed under strip-grazing with kikuyu grass (Cenchrus clandestinus), allowing 41-d regrowth periods. The area of the grazing strips was adjusted daily, providing $31 \mathrm{~kg}$ $\mathrm{DM} /$ cow/d. Grass dry matter (DM) concentration was $13.1 \pm 0.5 \%$ and its chemical composition (as DM\%) was as follows: CP: $24.7 \pm 1.6 \%$, ether extract (EE): $3.7 \pm 0.6 \%$, neutral detergent fiber (NDF): $52.9 \pm 3.9 \%$, acid detergent fiber (ADF): $29.8 \pm 2.4 \%$, lignin: $4.6 \pm 0.5 \%$, ash: $9.6 \pm 1.0 \%$, and NFC: $9.1 \pm 0.9 \%$. Nitrate concentration $\left(\mathrm{NO}_{3}\right)$ was 2,224.7 ppm. Energy density was $1.34 \pm 0.08$ Mcal net energy for lactation $\left(\mathrm{NE}_{\mathrm{L}}\right) / \mathrm{kg} \mathrm{DM}$.

Concentrate offer was based on weekly MY in a ratio close to $1: 3.5$ ( $1 \mathrm{~kg}$ concentrate per $3.5 \mathrm{~kg}$ milk). Four isoenergetic and isoprotein concentrates, corresponding to the experimental treatments, were compared. The Zea mays (ZM) treatment included corn grain as the main source of energy. In the remaining treatments, 50\% approximately of the total digestible nutrients (TDN) contributed by corn were provided by 
sorghum grain (Sorgum vulgare: SV), cassava root (Manihot esculenta: MES), or dehydrated citrus pulp (Citrus sp.: C) (Table 1 and 2). Concentrates were offered twice-a-day during milking, at 04:00 and 14:00 h.

\section{Chemical description of feed}

Samples were analyzed for DM, CP, EE, ash, $\alpha$-amilase NDF, ADF, Ca, P (AOAC, 2005; AOAC, 2007), lignin (Van Soest and Wine, 1968), gross energy (GE) (ISO, 1998), pectin (Hansen et al., 2001), starch (AOAC, 2000), amylose and amylopectin (Yun and Matheson, 1990). TDN and $\mathrm{NE}_{\mathrm{L}}$ were estimated with the model proposed by the NRC (2001). Condensed tannin content in sorghum grain was analyzed with the technique described by Dykes (2019). $\mathrm{NO}_{3}$ in kikuyu was determined with photocolorimetry as described by Spörndly et al. (2016).

\section{Dry matter intake}

Total dry matter intake $\left(\mathrm{DMI}_{\mathrm{T}}\right)$ corresponds to dry matter intake from pasture $\left(\mathrm{DMI}_{\mathrm{P}}\right)$ and concentrate $\left(\mathrm{DMI}_{\mathrm{C}}\right)$. The $\mathrm{DMI}_{\mathrm{C}}$ was calculated by difference between the feed offered and rejected. Chromium oxide was used as an external marker, and indigestible dry matter (IDM) was the internal marker (Correa et al., 2009) to determine DMI .

\section{Milk yield and quality}

Milk from the morning and afternoon milkings was weighed daily during the last three days of each experimental period (MM27BC automatic system, DeLaval International AB, Tumba, Stockholm, Sweden). The MY was corrected to $3.5 \%$ fat $(3.5 \% \mathrm{FCM})$ and also for energy (ECM) (Boerman et al., 2015). To evaluate milk quality, separate samples from morning and afternoon milkings were collected from each animal. A MilkoScan FT+ (Fourier Transform from Infrared; Foss, Hillerød, Denmark) was used to analyze samples for protein, fat, lactose, and total solids content $(\%)$. Somatic cell count $(\mathrm{SCC}$; cells $/ \mathrm{mL})$ was assessed by flow cytometry (Fossomatic ${ }^{\mathrm{TM}}$ FC, Foss Electric, Hillerød, Denmark). Feed efficiency $(\mathrm{FE})$, calculated from $\mathrm{MY}$ and $\mathrm{DMI}_{\mathrm{T}}$.
Table 1. Ingredients and chemical composition of the concentrates.

\begin{tabular}{|c|c|c|c|c|}
\hline Treatment & $\mathbf{Z M}$ & SV & MES & $\mathbf{C}$ \\
\hline \multicolumn{5}{|l|}{ Ingredient } \\
\hline Corn & 44.3 & 21.8 & 19.3 & 23.9 \\
\hline Sorghum* & - & 22.5 & - & - \\
\hline Cassava & - & - & 20.5 & - \\
\hline Citrus pulp & - & - & - & 25.8 \\
\hline Corn forage & 10.0 & 9.3 & 10.0 & 5.0 \\
\hline Wheat bran & 11.2 & 10.0 & 11.8 & 10.0 \\
\hline Rice flour & 8.6 & 10.8 & 11.7 & 7.6 \\
\hline Sunflower meal & 8.0 & 8.0 & 5.0 & 8.0 \\
\hline Soybean meal & 8.4 & 8.0 & 12.2 & 11.2 \\
\hline Molasses & 4.4 & 4.4 & 4.4 & 4.4 \\
\hline Calcium carbonate & 3.7 & 3.7 & 3.7 & 2.3 \\
\hline Sodium chloride & 0.86 & 0.89 & 0.91 & 0.81 \\
\hline Sodium bicarbonate & 0.30 & 0.30 & 0.30 & 0.30 \\
\hline Premix $* *$ & 0.20 & 0.20 & 0.20 & 0.20 \\
\hline Tricalcium phosphate & 0.17 & 0.10 & - & 0.58 \\
\hline \multicolumn{5}{|c|}{ Chemical composition (\%)*** } \\
\hline $\mathrm{DM}$ & 89.7 & 89.5 & 91.5 & 89.4 \\
\hline $\mathrm{CP}$ & 18.0 & 18.7 & 18.1 & 18.6 \\
\hline $\mathrm{EE}$ & 4.3 & 4.3 & 4.3 & 4.6 \\
\hline Ash & 8.6 & 8.8 & 9.5 & 8.4 \\
\hline $\mathrm{Ca}$ & 1.8 & 1.9 & 1.8 & 1.9 \\
\hline $\mathrm{Pt}$ & 0.7 & 0.7 & 0.7 & 0.7 \\
\hline $\mathrm{NDF}$ & 17.0 & 16.7 & 19.0 & 18.5 \\
\hline $\mathrm{ADF}$ & 8.4 & 9.0 & 8.4 & 12.6 \\
\hline NFC & 52.2 & 51.6 & 49.1 & 49.9 \\
\hline Lignin & 2.5 & 2.8 & 3.0 & 3.6 \\
\hline Pectin $* * * *$ & 1.4 & $<1.0$ & $<1.0$ & 8.9 \\
\hline GE, Mcal/kg & 4.4 & 4.4 & 4.3 & 4.4 \\
\hline $\mathrm{NE}_{\mathrm{L}}, \mathrm{Mcal} / \mathrm{kg}$ & 1.6 & 1.6 & 1.6 & 1.6 \\
\hline TDN & 71.4 & 70.6 & 71.0 & 71.8 \\
\hline
\end{tabular}

Zea mays (ZM), Sorghum vulgare (SV), Manihot esculenta (MES), and Citrus sp. (C).

* Sorghum with $954.5 \mathrm{mg}$ catechins/100g sample.

** Composition per $\mathrm{kg}$ of premix: 2,500,000 IU of vitamin A; $750,000 \mathrm{IU}$ of Vitamin $\mathrm{D}_{3} ; 2,000 \mathrm{IU}$ of Vitamin E; $12.5 \mathrm{~g}$ of $\mathrm{Fe} ; 2.5 \mathrm{~g}$ of $\mathrm{Cu} ; 10 \mathrm{~g}$ of $\mathrm{Mn} ; 10 \mathrm{~g}$ of $\mathrm{Zn} ; 0.15 \mathrm{~g}$ of I; $0.025 \mathrm{~g}$ of $\mathrm{Co} ; 30 \mathrm{~g}$ of antioxidant (BHT).

***Expressed in 100\% dry matter (DM): CP, crude protein; EE, ether extract; $\mathrm{Ca}$, calcium; $\mathrm{P}_{\mathrm{t}}$, total phosphorus; $\mathrm{NDF}$, neutral detergent fiber; ADF, acid detergent fiber; NFC, non-fibrous carbohydrates; $\mathrm{GE}$, gross energy; $\mathrm{NE}_{\mathrm{L}}$, net energy for lactation; TDN, total digestible nutrients. 
Table 2. Starch composition of ingredients and concentrates.

\begin{tabular}{lccc}
\hline & \multicolumn{3}{c}{ Nutrient } \\
\cline { 2 - 4 } & Starch $^{*}$ & Amylose $^{* * *}$ & Amylopectin $^{* *}$ \\
\hline In the ingredient & & & \\
Zea mays & 60.9 & 25.7 & 74.3 \\
Sorghum vulgare & 59.1 & 25.0 & 75.0 \\
Manihot & 69.0 & 20.7 & 79.3 \\
esculenta & & & \\
Citrus sp. & 2.4 & 9.3 & 90.7 \\
In the concentrate & & & \\
ZM & 30.4 & 21.7 & 78.3 \\
SV & 31.8 & 17.3 & 82.7 \\
MES & 25.6 & 19.9 & 80.1 \\
C & 21.2 & 18.0 & 82.0 \\
\hline
\end{tabular}

* Expressed as a percentage of DM.

** Expressed as a percentage of starch.

Zea mays (ZM), Sorghum vulgare (SV), Manihot esculenta (MES) and Citrus sp. (C).

Ruminal $p H$, rectal temperature and locomotion score

Ruminal $\mathrm{pH}$ was measured in the last $3 \mathrm{~d}$ of each experimental period using intraruminal boluses (eCow Ltd, Exeter, Devon, UK) (Mottram et al., 2008). The $\mathrm{pH}$ was measured every 60 seconds, taking average values every 15 minutes. The average, minimum, and maximum ruminal $\mathrm{pH}$ values were determined for $24-\mathrm{h}$ periods. Rectal temperature was measured on the last $3 \mathrm{~d}$ of each period at 09:00 and 15:00 h, and data were averaged per day. Locomotion score (LS) was assessed using a 1 to 5 scale (Sprecher et al., 1997) on the last day of each period. The animals were weighed on day 11 of each experimental period, and body condition score (BCS) was evaluated simultaneously.

Hematology, blood chemistry, and milk urea nitrogen

Blood samples were collected from the coccygeal vein on the $15^{\text {th }} d$ of each period (at 09:00 h). Parameters evaluated were: red blood cells (RBC), hemoglobin (Hb), hematocrit (HCT), mean corpuscular volume (MCV), mean corpuscular hemoglobin $(\mathrm{MCH})$, mean corpuscular hemoglobin concentration (MCHC), platelets (PLT), plateletcrit (PCT), mean platelet volume (MPV), platelet distribution width (PDW), white blood cells (WBC), and WBC differential (neutrophils, lymphocytes, monocytes, eosinophils, neutrophil: lymphocytes ratio) (Cell-Dyn system 3500 automated hematology analyzer; Abbott Laboratories, Abbott Park, IL, USA). Blood chemistry analysis included urea, creatinine, gamma glutamyl transferase (GGT), alkaline phosphatase (ALP), $\mathrm{Ca}, \mathrm{P}, \mathrm{Mg}$, total plasma proteins (TPP), albumin (ALB) and globulins (GLOB) (Vitros 250 Chemistry Analyzer, OrthoClinical Diagnostics, Markham, ON, Canada). Likewise, milk urea nitrogen (MUN) was determined with a MilkoScan FT+ (Fourier transform infrared; Foss, Hillerød, Denmark) using the same samples analyzed for quality.

\section{Statistical analysis}

Response variables were analyzed under a $4 \times 4$ replicated Latin square design using the MIXED procedure in SAS/STAT ${ }^{\circledR} 14.1$ software (SAS, 2015). A subsampling design was used to analyze rectal temperature and $\mathrm{pH}$ (Zamudio-Sanchez and Alvarado-Segura, 1996). Significant differences were declared at $\mathrm{p}<0.05$, and a tendency was declared at $0.05 \leq p \leq 0.10$. The BCS and LS were evaluated with Friedman's two-dimensional ANOVA by ranges for related samples $(5 \%$ statistical significance).

\section{Results}

Table 3 presents BW, BCS, DMI and forage: concentrate ratio ( $\mathrm{F}: \mathrm{C}$ ratio). No statistical difference was observed between treatments $(\mathrm{p}>0.05)$. MY, 3.5\% FCM, and lactose tended to differ $(p<0.10)$ with highest and lowest values for MES and $C$, respectively, which differed $(\mathrm{p}<0.05)$ in ECM, protein, and total solids in favor of MES. Protein was also different $(\mathrm{p}<0.05)$ between MES and SV (Table 4).

Table 5 presents the effect of treatment on ruminal $\mathrm{pH}$, rectal temperature, and LS. No differences were found between treatments $(p>0.05)$.

The $\mathrm{pH}$ dynamics is shown in Figure 1. 
Table 3. Body weight (BW), body condition score (BCS), dry matter intake (DMI), and forage: concentrate ratio (F:C ratio) of lactating cows supplemented with different carbohydrate sources.

\begin{tabular}{|c|c|c|c|c|c|c|}
\hline Item & $\mathbf{Z M}$ & SV & MES & C & SEM & p-value \\
\hline BW (kg) & 537.87 & 534.50 & 535.62 & 526.25 & 5.96 & 0.24 \\
\hline $\mathrm{BCS}$ & 3.03 & 3.03 & 3.03 & 2.94 & 0.04 & 0.59 \\
\hline \multicolumn{7}{|l|}{$\mathrm{DMI}_{\mathrm{T}}$} \\
\hline $\mathrm{kg} / \mathrm{d}$ & 19.36 & 20.77 & 20.47 & 19.20 & 0.57 & 0.77 \\
\hline $\mathrm{g} / \mathrm{kg}^{0.75} / \mathrm{d}$ & 174.28 & 187.28 & 184.34 & 181.27 & 5.33 & 0.79 \\
\hline$\% \mathrm{BW}$ & 3.63 & 3.90 & 3.84 & 3.79 & 0.11 & 0.79 \\
\hline \multicolumn{7}{|l|}{$\mathrm{DMI}_{\mathrm{P}}$} \\
\hline $\mathrm{kg} / \mathrm{d}$ & 11.58 & 12.18 & 12.35 & 11.62 & 0.54 & 0.93 \\
\hline $\mathrm{g} / \mathrm{kg}^{0.75 / \mathrm{d}}$ & 104.28 & 110.12 & 111.36 & 105.53 & 5.05 & 0.94 \\
\hline \%BW & 2.17 & 2.29 & 2.32 & 2.20 & 0.11 & 0.94 \\
\hline \multicolumn{7}{|l|}{$\mathrm{DMI}_{\mathrm{C}}$} \\
\hline $\mathrm{kg} / \mathrm{d}$ & 7.79 & 8.58 & 8.13 & 8.30 & 0.22 & 0.16 \\
\hline $\mathrm{g} / \mathrm{kg}^{0.75 / \mathrm{d}}$ & 70.00 & 77.16 & 72.98 & 75.74 & 2.00 & 0.17 \\
\hline$\% \mathrm{BW}$ & 1.46 & 1.61 & 1.52 & 1.58 & 0.04 & 0.17 \\
\hline $\mathrm{F}: \mathrm{C}$ ratio & $59.2: 40.8$ & $57.9: 42.1$ & $60.14: 39.86$ & $57.19: 42.81$ & 1.27 & 0.78 \\
\hline \multicolumn{7}{|c|}{ Intake, $\mathrm{kg} /$ day } \\
\hline NDF & 7.45 & 7.88 & 8.08 & 7.68 & 0.05 & 0.37 \\
\hline NFC & 5.12 & 5.54 & 5.11 & 5.20 & 0.04 & 0.53 \\
\hline
\end{tabular}

Treatments: Zea mays (ZM), Sorghum vulgare (SV), Manihot esculenta (MES), and Citrus sp. (C).

$\mathrm{BW}$, body weight; $\mathrm{BCS}$, body condition score; $\mathrm{DMI}_{\mathrm{p}}, \mathrm{DMI}_{\mathrm{C}}$ and $\mathrm{DMI}_{\mathrm{T}}$, pasture, concentrate and total dry matter intake; $\mathrm{F}: \mathrm{C}$ ratio, forage:concentrate; NDF, neutral detergent fiber; NFC, non-fiber carbohydrates.

SEM, Standard error of the mean.

Hematological parameters (Table 6) showed no differences between treatments $(\mathrm{p}>0.05)$.

Metabolic profile (Table 7) showed no differences between treatments $(\mathrm{p}>0.05)$.

\section{Discussion}

The chemical composition of kikuyu fits the values described by Correa et al. (2008). Despite different starch levels (Table 2), our concentrates were not different in NFC because citrus pulp is rich in sugar and pectin (Bampidis and Robinson, 2006).

No decrease in ruminal $\mathrm{pH}$ was found (Table 5), which explains the similar $\mathrm{DMI}_{\mathrm{T}}$, $\mathrm{DMI}_{\mathrm{p}}$, and $\mathrm{DMI}_{\mathrm{C}}$ observed between treatments (Table 3). The absence of ruminal acidosis could be due to the intake of NDF and NFC, and the
$\mathrm{F}: \mathrm{C}$ ratio, close to the $60: 40$ recommended in the literature (Mertens, 2009). Total NDF intake represented $38.5,37.9,39.4$, and $38.6 \%$ of $\mathrm{DMI}_{\mathrm{T}}$ for treatments ZM, SV, MES and C, respectively, while NDF consumption from forage was 31.6, $31.0,31.9$, and $30.9 \%$ of $\mathrm{DMI}_{\mathrm{T}}$, correspondingly. Therefore, NDF from forage fluctuated between 80.0 and $82.2 \%$ of total NDF intake. According to Mertens (1997), ruminant diets must contain at least $25 \% \mathrm{NDF}, 76 \%$ from forage. Krause and Oetzel (2006) suggest restricting NFC to 35$40 \%$ of $\mathrm{DMI}_{\mathrm{T}}$ to prevent SARA. In our study, NFC intake represented 26.4, 26.7, 25.0, and $26.1 \%$ of the $\mathrm{DMI}_{\mathrm{T}}$ for $\mathrm{ZM}, \mathrm{SV}$, MES and $\mathrm{C}$, respectively. In conclusion, the lack of difference in DMI between treatments reflects its similarity in nutritional characteristics without adversely affecting ruminal fermentation conditions. 
Table 4. Effect of carbohydrate source on yield and quality of milk, and feed efficiency.

\begin{tabular}{lcccccc}
\hline Item & ZM & SV & MES & C & SEM & p-value \\
\hline MY, kg/d & 32.15 & 31.33 & 33.55 & 30.63 & 1.11 & 0.07 \\
$3.5 \%$ FCM, kg/d & 32.12 & 32.18 & 35.19 & 31.33 & 1.10 & 0.06 \\
ECM, kg/d & $31.76^{\mathrm{ab}}$ & $31.42^{\mathrm{ab}}$ & $34.52^{\mathrm{a}}$ & $30.56^{\mathrm{b}}$ & 1.20 & 0.03 \\
Fat, \% & 3.50 & 3.67 & 3.83 & 3.72 & 0.14 & 0.52 \\
Protein, \% & 2.89 & 2.83 & 2.94 & 2.81 & 0.05 & 0.26 \\
Fat: protein ratio & 1.20 & 1.30 & 1.31 & 1.33 & 0.05 & 0.55 \\
Lactose, \% & 4.77 & 4.76 & 4.73 & 4.71 & 0.03 & 0.19 \\
Total solids, \% & 11.98 & 12.08 & 12.37 & 12.07 & 0.05 & 0.29 \\
Fat, $\mathrm{kg} / \mathrm{d}$ & 1.14 & 1.15 & 1.27 & 1.12 & 0.05 & 0.28 \\
Protein, kg/d & $0.93^{\mathrm{ab}}$ & $0.87^{\mathrm{b}}$ & $0.97 \mathrm{a}$ & $0.85^{\mathrm{b}}$ & 0.03 & 0.01 \\
Lactose, kg/d & 1.53 & 1.48 & 1.60 & 1.45 & 0.05 & 0.06 \\
Total solids, kg/d & $3.85^{\mathrm{ab}}$ & $3.77^{\mathrm{ab}}$ & $4.13^{\mathrm{a}}$ & $3.67^{\mathrm{b}}$ & 0.13 & 0.02 \\
SCC $\left(10^{3}\right.$ cells/mL) & 150 & 231 & 269 & 309 & 52.8 & 0.63 \\
FE & & & & & & \\
MY, kg/kg DMI & 1.66 & 1.51 & 1.64 & 1.54 & 0.06 & 0.64 \\
$3.5 \%$ FCM, kg/kg DMI & 1.66 & 1.55 & 1.72 & 1.63 & 0.07 & 0.82 \\
ECM, kg/kg DM & 1.64 & 1.51 & 1.68 & 1.59 & 0.07 & 0.74 \\
\hline
\end{tabular}

Treatments: Zea mays (ZM), Sorghum vulgare (SV), Manihot esculenta (MES), and Citrus sp. (C).

MY, milk yield; 3.5\% FCM, 3.5\% fat-corrected milk; ECM, energy-corrected milk; SCC, somatic cell count; FE, feed efficiency; DMI, dry matter intake.

SEM, Standard error of the mean.

Treatment means with different letters $(a, b)$ within the same row differ significantly $(p<0.05)$.

Table 5. Rumen $\mathrm{pH}$, rectal temperature and locomotion score (LS) of lactating cows supplemented with different carbohydrate sources.

\begin{tabular}{lcccccc}
\hline Ítem & ZM & SV & MES & C & SEM $^{2}$ & p-value \\
\hline Ruminal pH & & & & & & \\
$\quad$ Mean & 6.50 & 6.38 & 6.51 & 6.37 & 0.03 & 0.44 \\
Minimum & 6.16 & 6.12 & 6.20 & 6.00 & 0.03 & 0.52 \\
$\quad$ Maximum & 6.82 & 6.68 & 6.80 & 6.71 & 0.03 & 0.41 \\
Rectal temperature & 38.5 & 38.7 & 38.6 & 38.6 & 0.07 & 0.29 \\
LS & 1.38 & 1.13 & 1.13 & 1.13 & 0.07 & 0.39 \\
\hline
\end{tabular}

Treatments: Zea mays (ZM), Sorghum vulgare (SV), Manihot esculenta (MES), and Citrus sp. (C).

SEM, Standard error of the mean. 


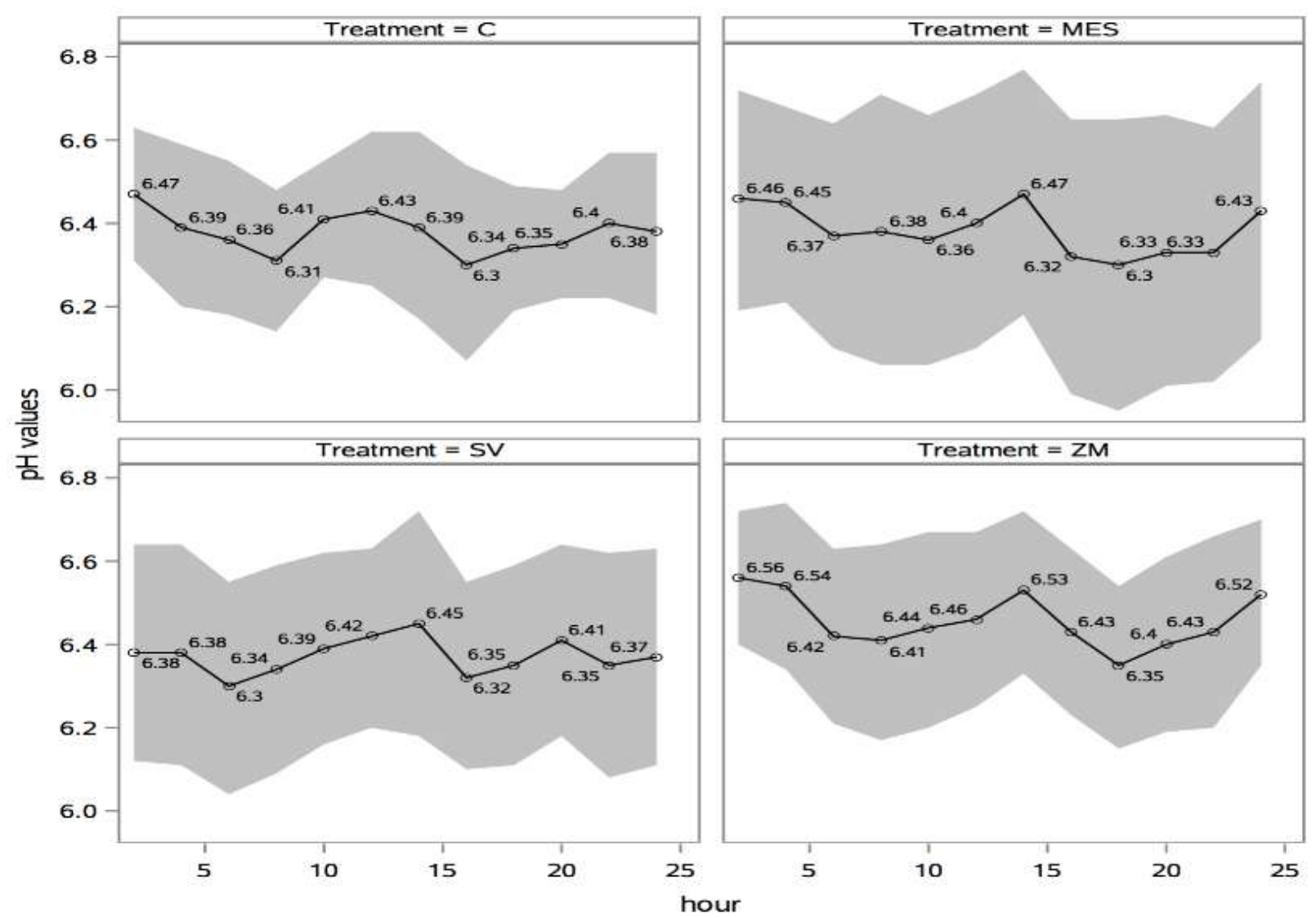

Figure 1. $\mathrm{pH}$ dynamics of lactating cows supplemented with different carbohydrate sources (Treatments: Zea mays (ZM), Sorghum vulgare (SV), Manihot esculenta (ME), and Citrus sp. (C)). The solid line represents the average pH obtained at 2-hour intervals. The gray shadow represents the standard deviation of the observations.

Performance differences between MES and $\mathrm{C}$ (Table 4) can be caused by differences in the ruminal degradation rate of carbohydrates and fermentation profile. Santos-Silva et al. (2016) suggested that pectin can interfere with ruminal fermentation because of its slightly lower rate and extent of degradation when compared to starch. According to Gómez et al. (2016), higher digestibility of cassava starch vs. starch from corn and sorghum is due to the lack of pericarp and protein matrix, less protein-starch association, lower proportion of corneous endosperm, lipids and amylose. Pectin increases the acetate molar proportion and reduces propionate molar proportion (Bampidis and Robinson, 2006). In contrast, starch fermentation tends to increase the propionate molar proportion (Ørskov, 1986), which is associated with an increase in glucose supply and MY (Khalili and Sairenen, 2000).
The greater milk protein and solids in MES vs. C resulted from greater MY and, to a lesser extent, a slight increase in their concentration (Table 4). Theurer et al. (1999) found increased MY and milk protein from greater ruminal digestion of starch. Lower milk protein in SV vs. MES (Table 4) can be explained by its lower starch fermentation (Offner et al., 2003) and high tannin content. Adetunji et al. (2013) reported catechins concentrations ranging between $0.09-0.33 \%$ in tannin-free sorghum and $0.37-1.34 \%$ in tannin sorghum. Sorghum catechins concentration in this study was $0.95 \%$.

According with milk fat results (Table 4) none of the treatments had a negative effect on ruminal $\mathrm{pH}$ or fiber digestibility. The fat:protein ratio (F/P; Table 4) was within the optimal range (1.2 to 1.4) reported by Čejna and Chládek (2005), again, confirming SARA absence $(\mathrm{G} / \mathrm{P}<1.2)$. 
Table 6. Hematological parameters of lactating cows supplemented with different carbohydrate sources.

\begin{tabular}{lcccccc}
\hline Ítem & ZM & SV & MES & C & SEM & p-value \\
\hline RBC $\left(10^{6} \mathrm{x} \square \mathrm{L}\right)$ & 6.11 & 6.08 & 6.20 & 6.10 & 0.14 & 0.90 \\
$\mathrm{Hb}(\mathrm{g} / \mathrm{dL})$ & 10.74 & 10.01 & 10.94 & 10.75 & 0.26 & 0.12 \\
$\mathrm{HCT}(\%)$ & 28.93 & 28.46 & 29.23 & 28.71 & 0.66 & 0.75 \\
$\mathrm{MCV}(\mathrm{fL})$ & 47.37 & 46.75 & 47.12 & 47.11 & 0.57 & 0.61 \\
MCH (pg) & 17.57 & 17.31 & 17.65 & 17.62 & 0.19 & 0.49 \\
MCHC (\%) & 37.06 & 36.96 & 37.52 & 37.50 & 0.18 & 0.55 \\
PLT (x 10 $\left.{ }^{3}\right)$ & 259.37 & 328.87 & 335.37 & 263.50 & 22.40 & 0.07 \\
PCT (\%) & 0.19 & 0.23 & 0.24 & 0.19 & 0.01 & 0.22 \\
MPV (fL) & 7.13 & 7.14 & 7.17 & 7.30 & 0.11 & 0.78 \\
PDW (\%) & 34.77 & 33.94 & 34.15 & 34.91 & 0.50 & 0.61 \\
WBC (10 x L) & 9.36 & 9.09 & 10.31 & 10.81 & 0.67 & 0.26 \\
WBC differential (\% WBC) & & & & & & \\
neutrophils (Neu) & 39.4 & 28.3 & 35.6 & 39.9 & 4.57 & 0.28 \\
lymphocytes (Lym) & 55.5 & 66.0 & 59.7 & 55.5 & 4.82 & 0.39 \\
monocytes & 0.12 & 0.63 & 0.25 & 0.13 & 0.28 & 0.57 \\
eosinophils & 5.03 & 5.05 & 4.32 & 4.51 & 0.89 & 0.91 \\
Neu:Lym ratio & 0.84 & 0.51 & 0.67 & 0.82 & 0.16 & 0.44 \\
\hline
\end{tabular}

Treatments: Zea mays (ZM), Sorghum vulgare (SV), Manihot esculenta (MES), and Citrus sp. (C).

$\mathrm{RBC}$, red blood cells; Hb, hemoglobin; HCT, hematocrit; MCV; mean corpuscular volume; $\mathrm{MCH}$, mean corpuscular hemoglobin; MCHC, mean corpuscular hemoglobin concentration; PLT, platelets; PCT, plateletcrit; MPV, mean platelet volume; PDW, platelet distribution width; WBC, white blood cells.

SEM, Standard error of the mean.

The SCC values were below the limit $(400 \times$ $10^{3}$ cells $/ \mathrm{mL}$ ) set in Europe, New Zealand and Australia (Sharma et al., 2011).

Under optimum conditions, FE should fluctuate between 1.4 and $1.8 \mathrm{~kg}$ of $3.5 \% \mathrm{FCM}$ per $\mathrm{kg}$ DMI (Hutjens, 2005), which is in line with our results (Table 4).

Once more, our results confirm the absence of SARA. It is also known that acidosis increases the heat produced per unit of digestible energy, resulting in lower net energy available for production (Casper and Mertens, 2007). SARA occurs when ruminal $\mathrm{pH}$ lower than 5.5 to 5.8 persists for several hours a day (Danscher et al., 2015). According to this, none of our treatments resulted in SARA (Table 5; Figure 1). Other factors, besides those discussed (F:C ratio, NDF and NFC consumption), can explain the absence of SARA in this work, namely, dietary $\mathrm{CP}$ and forage $\mathrm{NO}_{3}$. Based on $\mathrm{BW}, \mathrm{MY}$ and $\mathrm{DMI}_{\mathrm{T}}$, dietary CP should have been $15.6 \%$ to meet NRC (1988) requirements. However, it was $22.1 \pm$ $0.08 \%$, with $66.2 \pm 1.3 \%$ from kikuyu. It is known that more than $30 \%$ of kikuyu $\mathrm{CP}$ is rapidly and completely degraded in the rumen (Correa et al., 2008). High CP degradation releases ammonia, which captures protons $\left(\mathrm{H}^{+}\right)$due to its $\mathrm{pKa}(9.2$ dissociation constant) increasing $\mathrm{pH}$ (Bates and Pinching, 1949), which explains the buffer effect of CP in the present experiment. In our study, $\mathrm{NO}_{3}$ in kikuyu was between the range reported by Correa et al. (2008). As an electron acceptor, $\mathrm{NO}_{3}$ is reduced to $\mathrm{NH}_{4}^{+}$(Leng, 2008), buffering the ruminal $\mathrm{pH}$. Acidosis leads to gram-negative bacteria lysis, increasing lipopolysaccharide, which passes from rumen to blood causing fever, hypoperfusion of hoof capillaries, and laminitis (Kleen et al., 2003). No evident alterations in LS or rectal temperature were observed in our study, confirming once more the absence of SARA. 
Table 7. Metabolic profile of lactating cows supplemented with different carbohydrate sources.

\begin{tabular}{lcccccc}
\hline Ítem & ZM & SV & MES & C & SEM & p-value \\
\hline Metabolic function & & & & & & \\
Urea (mmol/L) & 7.27 & 6.68 & 6.84 & 6.34 & 0.48 & 0.59 \\
Creatinine ( $\square$ mol/L) & 79.1 & 77.4 & 75.8 & 79.7 & 2.0 & 0.54 \\
Hepatic function & & & & & & \\
GGT (U/L) & 21.8 & 24.3 & 22.2 & 24.9 & 1.5 & 0.38 \\
ALP (U/L) & 40.9 & 42.2 & 37.9 & 47.7 & 2.7 & 0.10 \\
Endocrine function & & & & & & \\
Ca (mmol/L) & 2.12 & 2.11 & 2.16 & 2.29 & 0.09 & 0.61 \\
P (mmol/L) & 1.71 & 1.85 & 1.91 & 1.77 & 0.11 & 0.64 \\
Mg (mmol/L) & 0.98 & 0.96 & 0.86 & 0.95 & 0.05 & 0.43 \\
TPP (g/dL) & 6.84 & 6.60 & 6.82 & 6.83 & 0.09 & 0.19 \\
ALB (g/L) & 3.42 & 3.17 & 3.32 & 3.31 & 0.08 & 0.19 \\
GLOB (g/L) & 3.41 & 3.43 & 3.54 & 3.52 & 0.07 & 0.50 \\
FBG (mg/dL) & 275 & 300 & 288 & 262 & 0.42 & 0.93 \\
ALB: GLOB ratio & 1.02 & 0.94 & 0.97 & 0.95 & 0.04 & 0.49 \\
(TPP-FB)/FBG & 5.84 & 5.60 & 5.81 & 5.83 & 0.09 & 0.19 \\
MUN (mg/dL) & 16.6 & 18.6 & 18.7 & 19.1 & 0.57 & 0.19 \\
\hline
\end{tabular}

Treatments: Zea mays (ZM), Sorghum vulgare (SV), Manihot esculenta (MES), and Citrus sp. (C).

GGT, gamma glutamyl transferase; ALP, alkaline phosphatase; Ca, calcium; P, phosphorus; Mg, magnesium; TPP, total plasma proteins; ALB, albumin; GLOB, globulins; FBG, fibrinogen; MUN, milk urea nitrogen.

SEM, Standard error of the mean.

Hematological parameters and metabolic profile were within reference values (Coroian et al., 2017; Botezatu et al., 2014; Radkowska et al., 2014), with the exception of MUN (Table 7). Optimal MUN in lactating cows fluctuates between 7 and $12 \mathrm{mg} / \mathrm{dL}$ (Hulsen et al., 2014), markedly lower than that observed in this work. As previously stated, CP consumption exceeded NRC (1988) requirement, and NFC was below the limit described by Krause and Oetzel (2006).

In conclusion, partial substitution of corn grain by sorghum grain, cassava root, or citrus pulp did not affect rumen $\mathrm{pH}$, DMI, or FE. Cows had a high intake of CP and NDF, while NFC intake was lower than that reported in the literature. These dietary characteristics protected the cows against SARA. The higher availability of energy from cassava increased MY, protein and total solids, contrary to the effect of citrus pulp inclusion.

\section{Declarations}

\section{Funding}

This study was funded by Ministerio de Ciencia, Tecnología e Innovación (MINCIENCIAS, Colombia) and Universidad de Antioquia (CODI 2018-2019).

\section{Conflicts of interest}

The authors declare they have no conflicts of interest with regard to the work presented in this report.

\section{Author contributions}

Sandra Lucia Posada-Ochoa and Ricardo Rosero-Noguera performed substantial contributions to the conception, design of the work, analysis and interpretation of data. Luis Miguel Gómez-Osorio carried out the experiment, performed the interpretation of 
data and drafting the work. Martha OliveraAngel contributed with the veterinary approach of the work. All authors discussed the results and contributed to the final manuscript.

\section{References}

Adetunji AI, Khoza S, de Kock HL, Taylor RN. Influence of sorghum grain type on wort physico-chemical and sensory quality in a whole-grain and commercial enzyme mashing process. J Inst Brew 2013; 119:156-163. DOI: https://doi.org/10.1002/jib.76

AOAC International. Official Methods of Analysis. $17^{\text {th }}$ ed. Gaithersburg, MD: AOAC International; 2000

AOAC International. Official Methods of Analysis. $18^{\text {th }}$ ed. Gaithersburg, MD: AOAC International; 2005

International. Official Methods of Analysis. 18th ed. Arlington, VA: AOAC International; 2007

Bampidis VA, Robinson PH. Citrus byproducts as ruminant feeds: A review. Anim Feed Sci Technol 2006; 128:175-217. DOI: https://doi.org/10.1016/j.anifeedsci.2005.12.002

Bates RG, Pinching GD. Acidic dissociation constant of ammonium ion at $0^{\circ}$ to $50^{\circ} \mathrm{C}$, and the base strength of ammonia. J Res Natl Bur Stand 1949; 42:419-430

Boerman JP, Potts SB, VandeHaar MJ, Lock AL. Effects of partly replacing dietary starch with fiber and fat on milk production and energy partitioning. J Dairy Sci 2015; 98:7264-7276. DOI: https://doi.org/10.3168/jds.2015-9467

Botezatu A, Vlagioiu C, Codreanu M, Oraşanu A. Biochemical and hematological profile in cattle effective. Bulletin UASVM Veterinary Medicine 2014; 71:27-30. DOI: http://dx.doi. org/10.15835/buasvmcn-vm:71:1:9544

Casper DP, Mertens DR. Feed efficiency of lactating dairy cows is related to dietary energy density. J Dairy Sci 2007; 90 (Suppl 1):407 (Abstr)
Čejna V, Chládek G. The importance of monitoring changes in milk fat to milk protein ratio in holstein cows during lactation. J Cent Eur Agric 2005; 6:539-546. DOI: https://www.researchgate.net/publication/27201776

Coroian CO, Mireşan V, Coroian A, Răducu A, Andronie L, Marchiş Z, Terheş S, Muntean MV. Biochemical and haematological blood parameters at different stages of lactation in cows. Bulletin UASVM Animal Science and Biotechnologies 2017; 74:31-36. DOI: http://dx.doi.org/10.15835/buasvmcn-asb:12283

Correa HJ, Pabón ML, Carulla JE. Valor nutricional del pasto kikuyo (Pennisetum clandestinum Hoechst Ex Chiov.) para la produccióndelecheen Colombia(Unarevisión): I-Composición química y digestibilidad ruminal y posruminal. Livest Res Rural Dev 2008; [access date: March 25, 2019] URL: http://www.lrrd.org/lrrd20/4/corra20059.htm

Correa HJ, Pabón ML, Carulla JE. Estimación del consumo de materia seca en vacas Holstein bajo pastoreo en el trópico alto de Antioquia. Livest Res Rural Dev 2009; [access date: March 30, 2019] URL: http://www.1rrd.org/lrrd21/4/corr21059.htm

Danscher AM, Shucong L, Andersen PH, Khafipour E, Kristensen NB, Plaizier JC. Indicators of induced subacute ruminal acidosis (SARA) in Danish Holstein cows. Acta Vet Scand 2015; 57:39-52. DOI: https://doi:10.1186/s13028-015-0128-9

Dykes L. Tannin analysis in sorghum grains: Methods and Protocols. In: Zhao ZY, Dahlberg J, editors. Sorghum Methods and Protocols. Basilea: Humana Press; 2019. p.109-120. DOI: https://doi.org/10.1007/978-1-4939-9039-9

Gao X, Oba M. Characteristics of dairy cows with a greater or lower risk of subacute ruminal acidosis: Volatile fatty acid absorption, rumen digestion, and expression of genes in rumen epithelial cells. J Dairy Sci 2016; 99:8733-8745. DOI: https://doi.org/10.3168/jds.2016-11570 
Gómez LM, Posada SL, Olivera M. Starch in ruminant diets. Rev Colomb Cienc Pecu 2016; 29:77-90. DOI: https://doi: 10.17533/udea.rccp.v29n2a01

Hansen KM, Truesen AB, Søderberg JR. Enzyme assay for identification of pectin and pectin derivatives, based on recombinant pectate lyase. JAOAC Int 2001; 84:1851-1854.

Hulsen J, Aerden D, Rodenburg J. Feeding signals. 2014. The Netherlands: J Agricultural Publishers; 2014.

Huntington GB, Harmon DL, Richards CJ. Sites, rates, and limits of starch digestion and glucose metabolism in growing cattle. J Anim Sci 2006; 84 Suppl: E14-24.

Hutjens MF. Dairy efficiency and dry matter intake. Proceedings of the 7th Western Dairy Management Conference; 2005; Reno, NV.

International Standards Organization-ISO. Animal feeding stuffs, animal products, and faeces or urine. Determination of gross calorific value-Bomb calorimeter method. Geneva, Switzerland; 1998.

Jing L, Dewanckele L, Vlaeminck B, Van Straalen WM, Koopmans A, Fievez V. Susceptibility of dairy cows to subacute ruminal acidosis is reflected in milk fatty acid proportions, with $\mathrm{C} 18: 1$ trans-10 as primary and $\mathrm{C} 15: 0$ and $\mathrm{C} 18: 1$ trans-11 as secondary indicators. J Dairy Sci 2018; 101:9827-9840. DOI: https://doi.org/10.3168/jds.2018-14903

Khalili H, Sairanen A. Effect of concentrate type on rumen fermentation and milk production of cows at pasture. Anim Feed Sci Technol 2000; 84:199-212. DOI: https://doi.org/10.1016/S0377-8401(00)00130-9

Kleen JL, Hooijer GA, Rehage J, Noordhuizen JP. Noordhuizen. Subacute ruminal acidosis (SARA): a review. J Vet Med A Physiol Pathol Clin Med 2003; 50:406-414. DOI: https://doi.org/10.1046/j.1439-0442.2003.00569.x
Krause KM, Oetzel GR. Understanding and preventing subacute ruminal acidosis in dairy herds: a review. Anim Feed Sci Technol 2006; 126:215-236. DOI: https://doi.org/10.1016/j.anifeedsci.2005.08.004

Leng RA. The potential of feeding nitrate to reduce enteric methane production in ruminants. A report to the department of climate change. Commonwealth Government of Australia. Canberra2008; [access date:April24,2019]URL: http://www.penambulbooks.com

Li S, Khafipour E, Krause DO, Kroeker A, Rodríguez-Lecompte JC, Gozho GN, Plaizier JC. Effects of subacute ruminal acidosis challenges on fermentation and endotoxins in the rumen and hindgut of dairy cows. J Dairy Sci 2012; 95:294-303. DOI: https://doi.org/10.3168/jds.2011-4447

Marais JP. Factors affecting the nutritive value of kikuyu grass (Pennisetum clandestinum)-a review. Tropical Grasslands 2001; 35(2): 65-84.

Mertens DR. Creating a system for meeting the fiber requirements of dairy cows. J Dairy Sci 1997; 80:1463-1481. DOI: https://doi.org/10.3168/jds.S0022-0302(97)76075-2

Mertens DR. Maximizing forage use by dairy cows. WCDS Adv Dairy Technol 2009; 21:303-319

Mottram T, Lowe J, McGowan M, Phillips N. Technical note: A wireless telemetric method of monitoring clinical acidosis in dairy cows. Comput Electron Agric 2008; 64:45-48. DOI: https://doi.org/10.1016/j.compag.2008.05.015

NRC. Nutrient Requirements of Dairy Cattle. 7th ed. Washington, DC: Natl Acad Sci; 2001.

NRC. Nutrient Requirements of Dairy Cattle. 6th ed. Washington, DC: Natl Acad Sci; 1988.

Offner A, Bach A, Sauvant D. Quantitative review of in situ starch degradation in the rumen. Anim Feed Sci Technol 2003; 106:81-93. DOI: https://doi.org/10.1016/S0377-8401(03)00038-5 
Ørskov ER. Starch digestion and utilization in ruminants. J Anim Sci 1986; 63:1624-1633. DOI: https://doi.org/10.2527/jas1986.6351624x

Radkowska I, Herbut E. Hematological and biochemical blood parameters in dairy cows depending on the management system. Anim Sci Pap Rep 2014; 32:317-325.

Santana A, Meireles A. New starches are the trend for industry applications: A review. Food Public Health 2014; 4:229-241. DOI: https://doi:10.5923/j.fph.20140405.04

Santos-Silva J, Dentinho MT, Francisco A,

Portugal AP, Belo AT, Martins APL, Alves SP, Bessa RJB. Replacing cereals with dehydrated citrus pulp in a soybean oil supplemented diet increases vaccenic and rumenic acids in ewe milk. J Dairy Sci 2016; 99:1173-1182. DOI: https://doi.org/10.3168/jds.2015-9966

SAS Institute Inc. SAS/STAT ${ }^{\circledR} 14.1$ User's Guide. Cary, NC, USA: SAS Institute Inc., 2015.

Sharma N, Singh NK, Bhadwal MS. Relationship of somatic cell count and mastitis: an overview. Asian-Australas J Anim Sci 2011; 24:429-438. DOI: https://doi.org/10.5713/ajas.2011.10233

Spörndly R, Grönqvist T, Knicky M, Ericson B. A note on sample preparation in the analysis of nitrate and nitrite in forage. Proceedings of the 7th Nordic Feed Science Conference; 2016 Sep 16; Uppsala, Sweden: Swedish University of Agricultural Sciences; 2016.
Sprecher DJ, Hosteler DE, Kaneene JB. A lameness scoring system that uses posture and gait to predict dairy cattle reproductive performance. Theriogenol 1997; 47:1179-1187. DOI: https://doi.org/10.1016/S0093-691X(97)00098-8

Tabasum S, Younas M, Ansab Zaeem M, Majeed I, Majeed M, Noreen A, Naeem Iqbal M, Mahmood Zia K. A review on blending of corn starch with natural and synthetic polymers, and inorganic nanoparticles with mathematical modeling. Int J Biol Macromol 2018; 122:969-996. DOI: https://doi.org/10.1016/j.ijbiomac.2018.10.092

Theurer CB, Huber JT, DelgadoElorduy A, Wanderley R. Invited review: summary of steam-flaking corn or sorghum grain for lactating dairy cows. J Dairy Sci 1999; 82:1950-1959. DOI: https://doi.org/10.3168/jds.S0022-0302(99)75431-7

Van Soest PJ, Wine RH. Determination of lignin and cellulose in acid-detergent fiber with permanganate. J AOAC Int 1968; 51:780-785.

Yun SH, Matheson NK. Estimation of amylose content of starches after precipitation of amylopectin by concavalin-A. Starch/Stärke 1990; 42:302 - 305. DOI: https://doi.org/10.1002/star.19900420805

Zamudio-Sánchez FJ, Alvarado-Segura AA. Análisis de diseños experimentales con igual número de submuestras. México: Universidad Autónoma Chapingo; 1996. 